\title{
Application of Value Engineering on Chassis Component for HCV — A Case Study
}

\author{
Prem Singh and Jagdeep Singh
}

\begin{abstract}
In these days Industries strives hard to meet the requirements of the customers and tries to reduce production cost by developing new alternatives. Value engineering is a scientific tool for reducing the cost while meeting the customer requirement. In the present work, the seven core steps of Value Engineering Job Plan (VEJP) were used to reduce the cost and improve value of a chassis component for a Heavy commercial vehicle (HCV). The study was carried out on ' $H$ type Shackle of Tata 2416 in medium class manufacturing Industry at Ludhiana. The study revealed the poor value areas, alternatives were developed and evaluated. At the end changes in design were proposed leading to $7.64 \%$ of cost saving and ease of manufacturing also helped yield a fourfold increase in the production.
\end{abstract}

Index Terms - Value engineering, VEJP, scientific tool, cost reduction, satisfaction.

\section{INTRODUCTION}

Value engineering is one of the most effective techniques available to identify and eliminate unnecessary costs in design, testing, manufacturing, construction, operations, maintenance, procedures specifications and practices. It involves the application of systematic planned procedure to obtain a desired effect by comparing the cost of component with respect to its purpose or functioning in the production or assembly. The most important aspect of 'VALUE' is difficult to define and often confused with the term cost or price but it is applied to both the subjective qualities (determined by the emotions) and objective qualities (determined by external characteristics).

Aristotle, way back in the year 350 B.C. classified value in seven classes which are still recognized today [1]-[6]. These are:

1) Economic,

2) Moral,

3) Aesthetics,

4) Social,

5) Political,

6) Religious,

7) Judicial.

Of these, only the economic value can be measure in the external units and other classes are subjectively scaled. Value Engineering is primarily concerned with the economic value so value in terms of its economic concept is defined as "The

Manuscript received May 11, 2015; revised October 27, 2015.

Prem Singh is with Guru Nanak Dev Engineering College, the Department of Mechanical Engineering, Ludhiana, India (e-mail: er.premsingh@gmail.com).

Jagdeep Singh is with Guru Nanak Dev Engineering College, the Department of Production Engineering, Ludhiana, India (e-mail: jagdeep829@gmail.com). lowest cost to reliably provide the required functions or service, at the desired time and place, and with essential quality"

\section{A. Systematic Approach of Value Engineering}

Value engineering has seven phases in job plan, developed step by step. These steps are followed systematically to achieve improvement in the project. This is explained in Table I

TABLE I: THE ARRANGEMENT OF CHANNELS

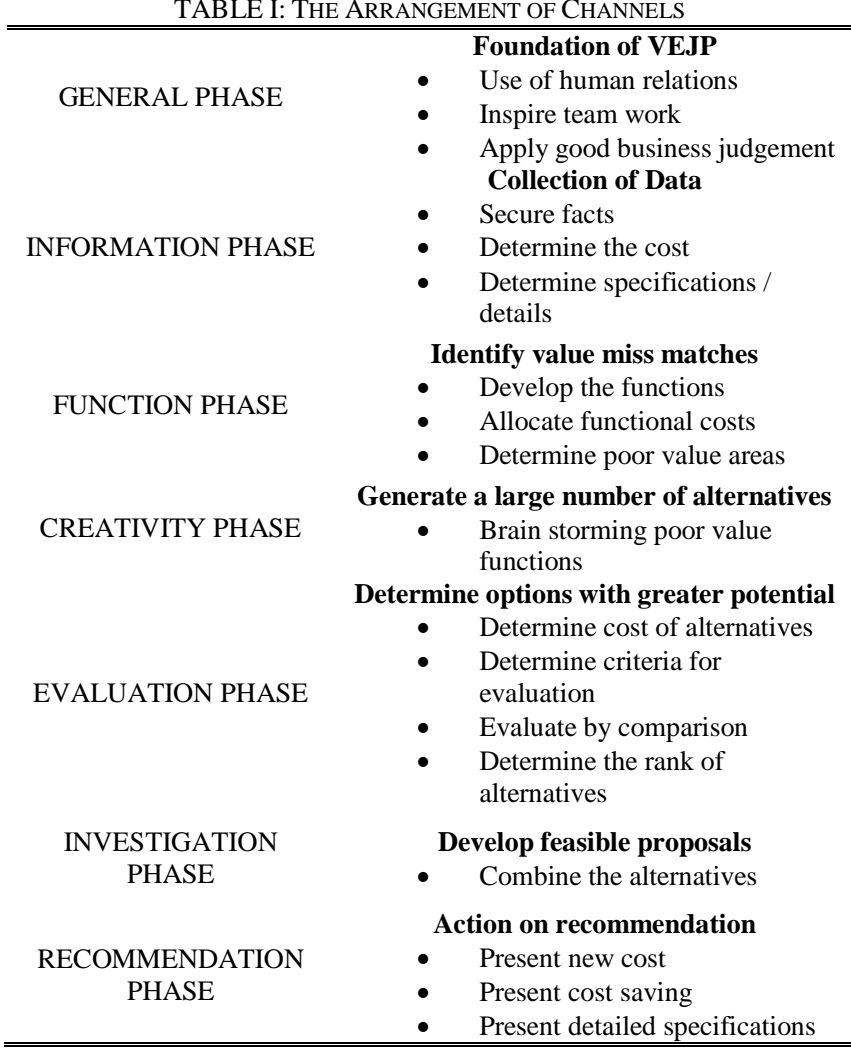

\section{LITERATURE REVIEW}

Ken performed value engineering study for the ideal target of process improvement. In this study, the researcher implemented the seven core steps of value job analysis plan. It was observed that in less than one year time, this exercise had helped yield the organization 1.5 times more savings than the total from the entire previous history of the program. It was highly recommended that any organization with a formal value engineering program duplicate this exercise in an effort to achieve similar results within their own program.

Heggade concluded that value engineering is a methodology which tries to reduce cost by improving functionality through lesser consumption of energy. The study shows that information technology could integrate the 
differentiated nature of the construction industry and play the role of incredible facilitator or enabler in both knowledge management and value engineering.

Ugo Ibusuki et al. suggested a methodology for the product development process in the automotive industry aiming at the correct systematic approach of value engineering and target-costing in cost management. The use of methodologies such as the target costing in cost management which are complimentary process and go hand in hand. While one allows the identification of where cost reduction could be achieved the other shows the target to be achieved to guarantee the long term profitability plan.

Manfield and Phillip reviewed and compared the true concept of value engineering in a construction company. The target was to define the unnecessary cost within the system that do not provide quality, use, life, appearance or construction features to the project, while the elimination of unnecessary costs through the performance of formal value engineering.

Jariri and Zegordi studied that cost in design process is an important issue. The methods and tools like Quality function deployment (QFD) and value engineering (VE) and target costing (TC) are the vital approach to design cost management. This study was based on the price, functionality, and quality using the inventive problem-solving and integration techniques. The research proposed that the second matrix of QFD in the best choice for VE approach.

Zhang et al. developed a more systematic creativity phase for the implementation of value engineering. The researchers developed the value engineering knowledge management system (VE-KMS). By applying this theory of creativity, they made the creativity phase more systematic, organized and problem focused. This attempt enhanced the creativity power of value engineers and the value engineering study and consequently enhanced the efficiency and effectiveness of the study.

From the literature review it has been observed that value engineering is very important tool for the improvement in the value of the product and reduce the overall manufacturing cost of the product.

\section{PRESENT WORK}

\section{A. Research Methodology}

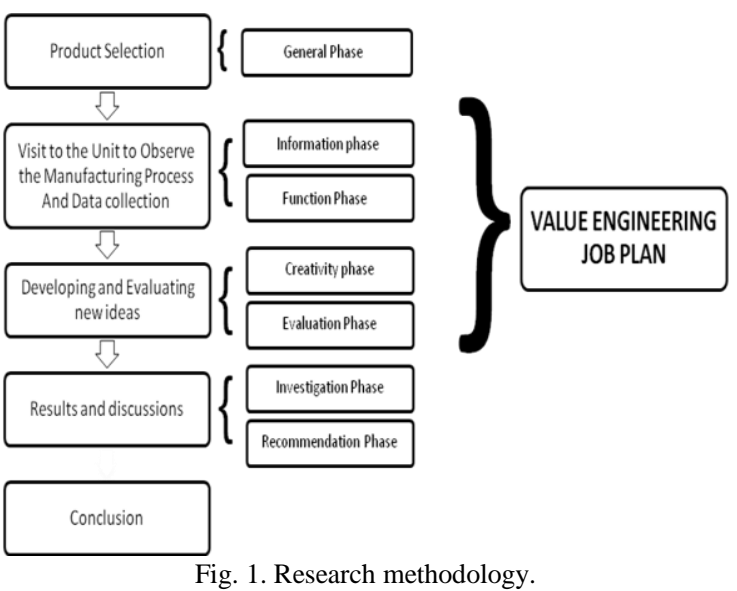

Fig. 1 shows the methodology used for the present study.

\section{B. Phase 1-General Phase}

This was the foundation phase of value engineering job plan. The selection of the project was the main activity in this phase. The guideline of this phase is followed in all other phases.

The five ground rules that were followed are: -

1) Use of good human relations

2) Inspire team work

3) Apply good business judgment

$\mathrm{H}$ type shackle for 2416 was taken for study which stratified the above mentioned considerations.

\section{Phase 2 - Information Phase}

In this phase, data and information related to the project was collected.

\section{1) Secure the facts}

The first step was to secure all relevant data and information regarding the company like its products, manufactured, the number of employees, organization chart etc.

The industry has twenty two employees and the company is involved in the manufacturing of various chassis components for LCV's and HCV's

\section{2) Manufacturing process}

The manufacturing process for $\mathrm{H}$ type shackle for TATA 2614 can be understood in the following manner. The shackle which is an assembly of three components i.e. 1) Front plate 2) Back plate 3) Spacer.

\section{3) Determining the cost and specifications}

The use of this technique was to determine the cost of the various components of the product so that the VE team identifies the poor value / high cost areas function phase of analysis. The total consideration of the direct material, direct labor and over heads costs. The components with their respective costs are given in Table II.

The dimensions of each component considered for the study and noted down and the drawings are made for recording the existing details of the component. The drawings are given in appendices. The major parts of the $\mathrm{H}$ type shackle for 2416 are shown in Fig. 2.

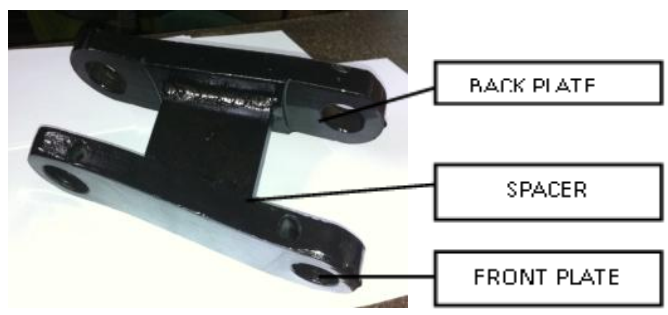

Fig. 2. 'H' type shackle for 2416 - Main parts.

\section{Phase 3 - Function Phase}

It is the function analysis that differentiates and distinguishes the value engineering technique from all other cost reduction

\section{E. Defining the Function}

The functions of all the parts of the $\mathrm{H}$ type shackle for 2416 were defined. Functions were classified as primary and secondary at the part level. To define the function closely, certain basic established rules were used. 
1) Primary Functions

2) Secondary Function

Function of all the components of the $\mathrm{H}$ type shackle for
2416 are defined in functional definition work sheet in Table III.

TABLE II: PART / PROCESS AND THEIR RESPECTIVE COST

\begin{tabular}{|c|c|c|c|c|c|c|c|}
\hline Part no. & Qty & Part Name / Action & Material /Process & $\begin{array}{l}\text { Gross } \\
\text { Weight(Kg) }\end{array}$ & Material Cost ( Rs ) & Machining Cost / Piece & $\begin{array}{l}\text { Total Cost } \\
(\mathrm{Rs})\end{array}$ \\
\hline 1 & 1 & Back plate & LC Steel & 4.20 & 185 & 5 & 190 \\
\hline 2 & 1 & Front Plate & LC Steel & 4.20 & 185 & 5 & 190 \\
\hline \multirow[t]{2}{*}{3} & 1 & Spacer & LC steel & 1 & 44 & 2 & 46 \\
\hline & & & & Machining & & & \\
\hline 4 & 1 & Assembling / Fabrication & Welding & & & 12 & 12 \\
\hline 5 & 1 & Boring $(\varnothing 35 \mathrm{~mm})$ & Boring & & & 2 & 2 \\
\hline 6 & 1 & $\begin{array}{l}\text { Boring } \\
(\varnothing 42 \mathrm{~mm})\end{array}$ & Boring & & & 2 & 2 \\
\hline 7 & 1 & Milling (66mm ) & Milling & & & 5 & 5 \\
\hline 8 & 1 & Milling (86mm ) & milling & & & 5 & 5 \\
\hline 9 & 4 & Cotter pin holes & Drilling & & & 6 & 6 \\
\hline Total & & & & & & & 458 \\
\hline
\end{tabular}

\begin{tabular}{|c|c|c|c|c|c|c|c|}
\hline \multirow{3}{*}{ S no } & \multirow{3}{*}{ Part } & \multicolumn{2}{|c|}{ Function Definition } & \multicolumn{4}{|c|}{ Function Level } \\
\hline & & \multirow{2}{*}{ Verb } & \multirow{2}{*}{ Noun } & \multicolumn{2}{|c|}{ Part } & \multicolumn{2}{|c|}{ Assembly } \\
\hline & & & & Primary & Secondary & Primary & Secondary \\
\hline \multirow{6}{*}{1} & \multirow{6}{*}{ Back plate } & Provide & Location & & $\sqrt{ }$ & \multirow{6}{*}{$\sqrt{ }$} & $\sqrt{ }$ \\
\hline & & Facilitate & Motion & & $\sqrt{ }$ & & $\sqrt{ }$ \\
\hline & & Join & Parts & & $\sqrt{ }$ & & $\sqrt{ }$ \\
\hline & & withstand & Impact & $\sqrt{ }$ & & & \\
\hline & & Provide & Support & & $\sqrt{ }$ & & $\sqrt{ }$ \\
\hline & & Provide & Location & & $\sqrt{ }$ & & $\sqrt{ }$ \\
\hline \multirow{6}{*}{2} & \multirow{5}{*}{ Front Plate } & Facilitate & Motion & & $\sqrt{ }$ & \multirow{6}{*}{$\sqrt{ }$} & $\sqrt{ }$ \\
\hline & & Join & parts & & $\sqrt{ }$ & & $\sqrt{ }$ \\
\hline & & Withstand & Impact & $\sqrt{ }$ & & & \\
\hline & & Permit & Retention & & $\sqrt{ }$ & & $\sqrt{ }$ \\
\hline & & Provide & Support & & $\sqrt{ }$ & & $\sqrt{ }$ \\
\hline & \multirow{4}{*}{ Spacer } & Provide & Location & & $\sqrt{ }$ & & $\sqrt{ }$ \\
\hline \multirow{3}{*}{3} & & Provide & Support & & $\sqrt{ }$ & \multirow{3}{*}{$\sqrt{ }$} & $\sqrt{ }$ \\
\hline & & Join & Parts & $\sqrt{ }$ & & & \\
\hline & & Bear & Load & & $\sqrt{ }$ & & $\sqrt{ }$ \\
\hline
\end{tabular}

\section{F. Evaluation of Functions}

For the evaluations of functional relationships, there is need to determine relative importance of various functions. This is determined through a paired comparison technique, which in turn led to evaluation.

\section{1) Numerical evaluation of functional relationships}

All the functions of all the parts under study are noted down from the functional definition worksheet and these listed functions are then allotted with key letters from A to F. these key letters are used throughout the succeeding comparison and evaluation of the function.

The comparison starts by relation function A to function B and deter mining which is more important. To decide the importance of a function, following weight factors are considered and allotted to the function depending on the difference of importance between them

\section{Weight Factors}

1) Minor difference in importance

2) Medium difference in importance

3) Major difference in importance

Numerical evaluation of functional relationship of various functions of $\mathrm{H}$ type shackle for 2416 is given in Table IV.

1) High Point (D): This indicated the basic function of the object studied.
2) First Leveling (D-F): Indicates the primary Functions that are in the project to meet specifications and requirements

3) First Drop (F-B): Separates the basic functions from the secondary one

4) Leveling (B-G-C-A): it includes the secondary functions that are a part of the project because of the present approach

\section{2) Function cost matrix and VIP index}

Now the percentage cost of each functions are divided by the percentage importance (weight factor), which give the value improvement potential (VIP) index for each function.

Functions having VIP index more than 1 are poor functions. Function cost matrix showing VIP index or parts or $\mathrm{H}$ type shackle for 2416 is given in Table V.

\section{3) Evaluation of manufacturing process}

The various processes involved in the manufacturing of the $\mathrm{H}$ type shackle for TATA 2416 were enlisted and evaluated. The details of the same have been recorded.

\section{G. Phase 4-Creative Phase}

Till now the component had been considered in its original form. Nothing had been done on the component to improve the quality or reduce the cost as per customer's specifications and functional requirements. On the basis of VIP, functions 
are identified as poor value functions. These are now considered in creative phase for improvement.

TABLE IV: NUMERICAL EVALUATION OF FUNCTIONS

\begin{tabular}{|c|c|c|c|c|c|c|c|c|}
\hline & & $\begin{array}{l}\text { Provide } \\
\text { Location }\end{array}$ & $\begin{array}{l}\text { Facilitate } \\
\text { Motion }\end{array}$ & $\begin{array}{l}\text { Join } \\
\text { Parts }\end{array}$ & $\begin{array}{l}\text { Withstand } \\
\text { Impact }\end{array}$ & $\begin{array}{l}\text { Permit } \\
\text { Retention }\end{array}$ & $\begin{array}{l}\text { Bear } \\
\text { Load }\end{array}$ & $\begin{array}{l}\text { Provide } \\
\text { support }\end{array}$ \\
\hline Part Name & T. Cost (Rs) & A & $\mathrm{B}$ & $\mathrm{C}$ & $\mathrm{D}$ & $\mathrm{E}$ & $\mathrm{F}$ & G \\
\hline Back Plate & 190 & 38 & 38 & 38 & 38 & & & 38 \\
\hline Front Plate & 190 & 31 & 31 & 31 & 31 & 31 & 6 & 31 \\
\hline Spacer & 46 & 11 & & 11 & & & 15 & 11 \\
\hline Total cost & 426 & 80 & 69 & 80 & 69 & 31 & 21 & 80 \\
\hline $\begin{array}{l}\% \text { cost } \\
\% \text { weight }\end{array}$ & & $\begin{array}{l}18.77 \\
3.84\end{array}$ & $\begin{array}{l}16.19 \\
13.46\end{array}$ & $\begin{array}{l}18.77 \\
9.61\end{array}$ & $\begin{array}{l}16.19 \\
30.75\end{array}$ & $\begin{array}{l}7.27 \\
1.92\end{array}$ & $\begin{array}{l}4.92 \\
28.84\end{array}$ & $\begin{array}{l}18.77 \\
11.53\end{array}$ \\
\hline $\begin{array}{l}\text { VIP } \\
\text { INDEX }\end{array}$ & & 4.88 & 1.20 & 1.95 & 0.54 & 3.78 & 0.17 & 1.56 \\
\hline
\end{tabular}

TABLE V: VIP INDEX

\begin{tabular}{|c|c|c|c|c|c|c|c|c|c|c|}
\hline & & $\mathrm{B}$ & $\mathrm{C}$ & $\mathrm{D}$ & $\mathrm{E}$ & $\mathrm{F}$ & G & Total Wt. & Adj. Wt. & \%age Adj. Wt \\
\hline & A & B2 & $\mathrm{C} 2$ & D3 & A1 & $\mathrm{F} 3$ & $\mathrm{~A} 2$ & 1 & 2 & 3.84 \\
\hline & & B & B2 & D3 & B2 & F3 & $\mathrm{G} 2$ & 6 & 7 & 13.46 \\
\hline & & & $\mathrm{C}$ & D3 & $\mathrm{C} 1$ & F3 & $\mathrm{C} 1$ & 4 & 5 & 9.61 \\
\hline & & & & $\mathrm{D}$ & D3 & D1 & D2 & 15 & 16 & 30.76 \\
\hline & & & & & $\mathrm{E}$ & F3 & G3 & 0 & 1 & 1.92 \\
\hline & & & & & & $\mathrm{F}$ & $\mathrm{F} 2$ & 14 & 15 & 28.84 \\
\hline & & & & & & & G & 5 & 6 & 11.53 \\
\hline Key Letter & \multicolumn{5}{|c|}{ Function } & & & & 52 & 100 \\
\hline $\mathrm{A}$ & \multicolumn{5}{|c|}{ Provide Location } & & & & & \\
\hline B & \multicolumn{5}{|c|}{ Facilitate Motion } & & & & & \\
\hline $\mathrm{C}$ & \multicolumn{5}{|c|}{ Join Parts } & & & \multirow{2}{*}{\multicolumn{3}{|c|}{$\begin{array}{l}\text { Evaluation Weight Factor } \\
\text { (Difference in Importance ) }\end{array}$}} \\
\hline $\mathrm{D}$ & \multicolumn{5}{|c|}{ Withstand Impact } & & & & & \\
\hline$E$ & \multicolumn{5}{|c|}{ Permit Retention } & & & 1 & \multicolumn{2}{|c|}{ Minor Difference } \\
\hline $\bar{F}$ & \multicolumn{5}{|c|}{ Bear Load } & & & 2 & \multicolumn{2}{|c|}{ Medium Difference } \\
\hline $\mathrm{G}$ & \multicolumn{5}{|c|}{ Provide Support } & & & 3 & \multicolumn{2}{|c|}{ Major Difference } \\
\hline
\end{tabular}

\section{1) Establish positive thinking}

"The mind is like a parachute - it works only when it is open" Establishing the positive thinking is must to develop creativity. It helps o develop a state of mind in which one could think positively through the open mind and develop number of ideas to achieve required function.

\section{2) Develop creative idea}

Functions considered for creativity phase are taken separately by making groups of parts and the poor value functions accomplished by these selected parts.

Creative Work Sheet

H type Shackle for 2416

Ideas regarding design:

1) Reduce the length of the side and the frond plate

2) Reduce the length size of the spacer

3) Reduce the thickness of the front plate by $2 \mathrm{~mm}$

4) Reduce the thickness of the back plate by $2 \mathrm{~mm}$

5) Reduce the thickness of both the front and the back plates both by $2 \mathrm{~mm}$

Ideas regarding manufacturing process:

1) Replace the side grinding process with a special draw die

2) Replace the initial drill size $\emptyset 31 \mathrm{~mm}$ and $\varnothing 38 \mathrm{~mm}$ with a die that can be used on a press

3) Reduce the cotter pin holes from four to two

\section{H. Phase 5-Evaluation Phase}

The cost on all feasible ideas is established. For this purpose ideas are rated in the following manner:

\footnotetext{
' $A$ ' — an acceptable idea
}

'U' — an unacceptable idea
After this, appraisal of ideas is carried out on the basis of estimating the cost of idea. High cost ideas, having cost no more than the present cost are eliminated and low cost ideas are taken up further for comparison.

Now for the evaluation by comparison, developed workable solutions are compared on the basis of suitable criteria or parameters. For comparison purpose, 'Decision Matrix' is made to find value scores of each workable solution.

\section{1) Establishing cost ideas}

Now, the cost of unacceptable ideas is estimated and allocated and reasons for unaccepting an idea is given. The percentage saving over present design cost is given in ' \{\} ' brackets. This is given in the functional development worksheet from Table VI.

\section{2) Evaluation}

After allocating the cost to the ideas, they are evaluated by comparison by using appropriate criteria of evaluation, for selecting the final acceptable ideas.

\section{a) Criteria of evaluation}

The evaluation criteria suitable for this study were:
A: Cost saving
B: Ease of implementation
C: Durability
D: Ease of operation

These criteria are then numerically evaluated by paired comparison for giving rank or grade to each criterion. This is presented in Table VII. 


\section{b) Decision matrix}

The decision matrix is made finally selecting the suitable alternative by ranking. The ideas are ranked by finding value scores of ideas using weights from of selection criteria and a five point scale mentioned as under. The same had been taken from the research work of Singh Amandeep's study.

TABLE VI: FunCTIONAL DEVELOPMENT WORK SHEET NO. 1

\begin{tabular}{|c|c|c|c|}
\hline $\begin{array}{c}\text { S } \\
\text { No }\end{array}$ & Idea & $\begin{array}{l}\text { Status of } \\
\text { Idea 'A' or } \\
\text { ' } U \text { ' }\end{array}$ & $\begin{array}{l}\text { Cost if ' } A \text { ', } \\
\text { Reason if ' } U \text { ', }\end{array}$ \\
\hline 1 & $\begin{array}{l}\text { Reduce the length of the back and the } \\
\text { frond plate }\end{array}$ & $\mathrm{U}$ & $\begin{array}{l}\text { The } \mathrm{H} \text { type shackle for } 2416 \text { connects the chassis of the trailer with the leaf springs } \\
\text { using a spring pin. So if the length of the front plate is reduced, it would hamper the } \\
\text { fitting which is not allowable }\end{array}$ \\
\hline 2 & Reduce the length size of the spacer & $\mathrm{U}$ & $\begin{array}{l}\text { The spacer Is the part that keeps the assembly together. If its size is reduced it would } \\
\text { cause twisting of the assembly causing accident }\end{array}$ \\
\hline 3 & $\begin{array}{l}\text { Reduce the thickness of the front plate } \\
\text { by } 2 \mathrm{~mm}\end{array}$ & A & $\begin{array}{l}\text { After the milling operation has been done, the effective thickness reduces to } 22 \mathrm{~mm} \text {. this } \\
\text { is a possible way. } \\
\text { This could reduce the cost of front plate to Rs } 175-00 \\
\{\text { saving } 3.27 \% \text { \} }\end{array}$ \\
\hline 4 & $\begin{array}{l}\text { Reduce the thickness of the back plate } \\
\text { By } 2 \mathrm{~mm}\end{array}$ & A & $\begin{array}{l}\text { After the milling operation has been done, the effective thickness reduces to } 22 \mathrm{~mm} \text {. this } \\
\text { is a possible way. } \\
\text { This could reduce the cost of back plate to Rs } 175-00 \\
\{\text { saving } 3.27 \% \text { \} }\end{array}$ \\
\hline 5 & $\begin{array}{l}\text { Reduce the thickness of both the front } \\
\text { and the back plates both by } 2 \mathrm{~mm}\end{array}$ & A & $\begin{array}{l}\text { Since the effective are on the plate remains the same, this is practical and possible. } \\
\{\text { saving } 6.55 \%\}\end{array}$ \\
\hline 1 & $\begin{array}{l}\text { Replace the side grinding process with a } \\
\text { special draw die }\end{array}$ & A & $\begin{array}{l}\text { the cut piece is pushed through the die thus finishing it in a single stroke. This increased } \\
\text { the production and improved the overall finish of the front and the back plate }\end{array}$ \\
\hline 2 & $\begin{array}{l}\text { Replace the initial drill size } \emptyset 31 \mathrm{~mm} \text { and } \\
\emptyset 38 \mathrm{~mm} \text { with a die that can be used on a } \\
\text { press }\end{array}$ & A & $\begin{array}{l}\text { The holes which otherwise take time and involve drills that are consumed at a high rate } \\
\text { as compared to a die tool. } \\
\text { The die also makes it easy to handle the scrap which in this case is much easier to } \\
\text { handle. Thus increasing the production as well as the saving. }\end{array}$ \\
\hline 3 & $\begin{array}{l}\text { Reduce the cotter pin holes from four to } \\
\text { two }\end{array}$ & A & $\begin{array}{l}\text { A slight modification in the spring pin and only two holes instead of four holes can } \\
\text { solve the purpose. } \\
\text { This will double the production on this machine and reduce the machining cost to half }\end{array}$ \\
\hline
\end{tabular}

\begin{tabular}{|c|c|c|c|c|c|}
\hline & \multicolumn{5}{|c|}{ TABLE VII: WEIGHT OF EVOLUTION CRITERIA } \\
\hline & $B$ & $C$ & $D$ & $\begin{array}{l}\text { Total } \\
\text { weight }\end{array}$ & Adj weight \\
\hline \multirow[t]{4}{*}{$A$} & $A 3$ & C1 & D1 & 3 & 4 \\
\hline & $B$ & $C 1$ & $D 2$ & 0 & 1 \\
\hline & & $C$ & D1 & 2 & 3 \\
\hline & & & $D$ & 4 & 5 \\
\hline
\end{tabular}

The technique used to assign points to idea for each criterion is consulting with the experts (experienced manufacturers, customers and workers operating the various machines). The cost savings are given points on the basis of saving percentage of the present design cost based on Table VIII and Table IX.

TABLE VIII: SCALES BASED ON COST SAVING / EASE OF EVALUATION / DURABILITY / EASE OF OPERATION

\begin{tabular}{llll}
\hline \hline Cost Saving & Points & Criteria of evaluation \\
\hline More than $20 \%$ & 5 & Excellent & Point \\
Between $15 \%$ to $20 \%$ & 4 & Very good & 4 \\
Between $10 \%$ to $15 \%$ & 3 & Good & 3 \\
Between $5 \%$ to $10 \%$ & 2 & Fair & 2 \\
Less than $5 \%$ & 1 & Poor & 1 \\
\hline \hline
\end{tabular}

\begin{tabular}{|c|c|c|c|c|c|}
\hline Desired Criteria with wt & $\begin{array}{l}A=4 \\
\text { (Points) }\end{array}$ & $\begin{array}{l}\text { B=1 } \\
\text { (Points) }\end{array}$ & $\begin{array}{l}\mathrm{C}=\mathbf{3} \\
\text { (Points) }\end{array}$ & $\begin{array}{l}\mathrm{D}=5 \\
\text { (Points) }\end{array}$ & Total score \\
\hline$\Rightarrow$ & Score & Score & Score & Score & \\
\hline Reduce the thickness of the front plate & (2) & (3) & (4) & (4) & \\
\hline Reduce the thickness of the back plate & $\begin{array}{l}8 \\
(2)\end{array}$ & $\begin{array}{l}3 \\
(3)\end{array}$ & $\begin{array}{l}12 \\
(4)\end{array}$ & $\begin{array}{l}20 \\
(4)\end{array}$ & 43 \\
\hline Reduce the thickness of both the front and the back plates & $\begin{array}{l}8 \\
(5)\end{array}$ & $\begin{array}{l}3 \\
(3)\end{array}$ & $\begin{array}{l}12 \\
(4)\end{array}$ & $\begin{array}{l}20 \\
(5)\end{array}$ & 43 \\
\hline Replace the side grinding process with a special draw die & $\begin{array}{l}20 \\
(4)\end{array}$ & $\begin{array}{l}3 \\
(4)\end{array}$ & $\begin{array}{l}12 \\
(5)\end{array}$ & $\begin{array}{l}25 \\
(4)\end{array}$ & $60 \#$ \\
\hline Replace the initial drill size $\varnothing 31 \mathrm{~mm}$ and $\varnothing 38 \mathrm{~mm}$ with a die that can be used on a press & $\begin{array}{l}16 \\
(4)\end{array}$ & $\begin{array}{l}4 \\
(4)\end{array}$ & $\begin{array}{l}15 \\
(4)\end{array}$ & $\begin{array}{l}20 \\
(4)\end{array}$ & 55 \\
\hline Reduce the cotter pin holes from four to two & $\begin{array}{l}16 \\
(2)\end{array}$ & $\begin{array}{l}4 \\
(5)\end{array}$ & $\begin{array}{l}12 \\
(3)\end{array}$ & $\begin{array}{l}20 \\
(4)\end{array}$ & 55 \\
\hline & 8 & 5 & 9 & 20 & 42 \\
\hline
\end{tabular}




\section{RESUlt AND DISCUSSION}

The suggested modifications are:

1) Reduce the size of the front and the back plate by $2 \mathrm{~mm}$ i.e. the cross section of the bar now would be $70 \mathrm{~mm} \times$ $23 \mathrm{~mm}$

2) Increase the size of the spacer by $4 \mathrm{~mm}$

3) The side grinding operation be replaced by a single stroke draw die on a press tool
4) The double head drilling be replaced by a single stroke punching die used again on a press tool

\section{A. Cost Analysis}

Table $\mathrm{X}$ shows the new bill of materials prepared after modification, addition and also by elimination of some parts after value engineering. The comparison of the old and the new costs had been depicted in Table XI.

TABLE X: PART / PROCESS AND THEIR RESPECTIVE COSTS (MODIFIED)

\begin{tabular}{|c|c|c|c|c|c|c|c|}
\hline Part no. & Qty & Part Name / Action & Material/Process & $\begin{array}{c}\text { Gross } \\
\text { Weight }(\mathrm{Kg})\end{array}$ & $\begin{array}{l}\text { Material Cost } \\
\text { ( Rs ) }\end{array}$ & $\begin{array}{c}\text { Machining Cost / } \\
\text { Piece }\end{array}$ & Total Cost ( Rs ) \\
\hline $\mathbf{1}$ & $\mathbf{1}$ & Back plate & LC Steel & $3-860$ & 170-00 & $5-00$ & 175-00 \\
\hline 2 & 1 & Front Plate & LC Steel & 3-860 & $170-00$ & $5-00$ & $175-00$ \\
\hline 3 & 1 & Spacer & LC steel & $\begin{array}{c}1-050 \\
\text { Machining }\end{array}$ & 46-00 & 2-00 & 48-00 \\
\hline 4 & 1 & $\begin{array}{c}\text { Assembling / } \\
\text { Fabrication }\end{array}$ & Welding & & & 12-00 & 12-00 \\
\hline 5 & 1 & Boring (Ø35mm) & Boring & & & 2-00 & 2-00 \\
\hline 6 & 1 & $\begin{array}{c}\text { Boring } \\
(\emptyset 42 \mathrm{~mm})\end{array}$ & Boring & & & 2-00 & 2-00 \\
\hline 7 & 1 & Milling (66mm ) & Milling & & & $1-70$ & $1-70$ \\
\hline 8 & 1 & Milling (86mm ) & milling & & & $1-70$ & $1-70$ \\
\hline 9 & 4 & Cotter pin holes & Drilling & & & 6-00 & 6-00 \\
\hline \multicolumn{7}{|c|}{ Total } & 423-00 \\
\hline
\end{tabular}

TABLE XI: COST COMPARISON

\begin{tabular}{llrr}
\hline \hline S & Part Name / Action & Cost - Old & Cost - New \\
No & & & \\
\hline 1 & Back Plate & $190-00$ & $175-00$ \\
2 & Front Plate & $190-00$ & $175-00$ \\
3 & Spacer & $46-00$ & $48-00$ \\
& & & \\
4 & Assembling / Fabrication & $12-00$ & $12-00$ \\
5 & Boring (Ø35mm) & $2-00$ & $2-00$ \\
6 & Boring & $2-00$ & $2-00$ \\
& (Ø42mm ) & & \\
7 & Milling (66mm ) & $5-00$ & $1-70$ \\
8 & Milling (86mm ) & $5-00$ & $1-70$ \\
9 & Cotter pin holes & $6-00$ & $6-00$ \\
TOTAL & $\mathbf{4 5 8 - 0 0}$ & $\mathbf{4 2 3 - 0 0}$ \\
\hline \hline
\end{tabular}

Cost saving after VE $=$ Cost before $\mathrm{VE}-$ Cost after VE $=458-00-423-00=$ Rs $35-00$

Percentage Saving $=(35-00 / 458-00) \times 100=7.64 \%$

The company was already selling 2500 pieces of the $\mathrm{H}$ type shackle for 2416 in a month i.e 30,000 pieces per year, which implies.

Annual Saving $=$ Rs $35-00 \times 30,000=R s$ 10,50,000-00

\section{B. Manufacturing Process Advantage}

1) The replacement of the side grinding with a draw die results in:

- The initial cost of the machine tool already being used was Rs 75000-00. This was substituted with a draw die which was made with an initial expenditure of Rs 25000-00.

- In terms of production, on the existing setup, the production was $7000 \mathrm{pc} /$ month which was increased to 1400 pieces / day i.e. a month's work done in just 5 days.

- The recurring cost of machining which was in the form of the grinding was Rs 1700 / wheel and the monthly expense was Rs 2500 where as in the improved case, the recurring expense was just Rs 100 / polishing of the die i.e. monthly expense of Rs 100 only.
2) By replacing drilling process with a die punching process results in:

- The initial cost of the machine tool already being used was Rs 90,000-00. This was substituted with a punching die which was made with an initial expenditure of Rs 25000-00.

- In terms of production, on the existing setup, the production was $7500 \mathrm{pc} /$ month which was increased to 1200 pieces / day i.e. a month's work done in just 6-7 days.

- The recurring cost of machining which was in the form of the grinding was Rs 7900 / set of 2 drills and the monthly expense was Rs 9000 where as in the improved case, the recurring expense was just Rs 50 / polishing of the die i.e. monthly expense of Rs 500 only.

\section{CONCLUSIONS}

Value Engineering Job Plan study led to saving Rs 35 per piece for the $\mathrm{H}$ type shackle for 2416 which is a $7.64 \%$ saving. Average annual saving is Rs 10, 50,000-00 for this component. The improvement in the manufacturing processes increased the production for the drilling and the grinding process by four times. Increase in the gap of the assembly reduced the cost and effort of milling. It reduced the milling cost / piece from to Rs 10 to Rs 3.40 i.e. a saving of $34 \%$.

\section{REFERENCES}

[1] L. Ken and Smith, "Applying value analysis to a value engineering program," American Association of State Highway and Transportation Officials (AAHSTO) VE Conference, May 1999.

[2] V. N. Heggade, "IT-propelled value engineering in construction," The Indian Concrete Journal, pp. 222-226. Nov. 2002.

[3] U. Ibusuki and P. C. Kaminski, "Product development process with focus on value engineering and target-costing: A case study in an automotive company," International Journal Production Economics, vol. 105, pp. 459-474, Jan. 2004.

[4] M. Stephen and D. Phillip, "Application of value engineering within the construction industry," 2006. 
[5] F. Jariri and S. H. Zegordi, "Quality function deployment, value engineering and target costing, an integrated frame work in design cost management: A mathematical programming approach," Sharif University of Technology Scientia Iranica, vol. 15, pp. 405-411. Nov. 2008.

[6] X. Zhang and X. Mao, "Developing a knowledge management system for improved value engineering practices in the construction industry," Automation in construction, vol. 18, pp. 779 - 789, July 2009.

Prem Singh did the M.Tech in mechanical engineering from Punjab Agriculture University, Ludhiana, Punjab, India and Prem Singh is working as an assistant professor in the Department of Mechanical Engineering at Guru Nanak Dev Engineering College, Ludhiana, Punjab, India.

Jagdeep Singh did the M.Tech in industrial engineering from Punjab Technical University, Jalandhar, Punjab, India and Jagdeep Singh is working as an assistant professor in the Department of Production Engineering at Guru Nanak Dev Engineering College, Ludhiana, Punjab, India. 